\title{
Determinants of Profitability of Teff Producer Farmers in Menjar Shenkora Worda, North Shewa Zone, Amhara Regional State, Ethiopia
}

\author{
Zerihun Demessie Ayele \\ North Shewa Zone Disaster Prevention, Food Security Program, \\ Early Warning Department, Amhara Region, Ethiopia \\ Getamesay Bekele Meshesha(PhD) \\ Department of Development Economics, Faculty of Policy and Development Studies, \\ Federal Melse Zenawi Leadership Academy, Addis Ababa, Ethiopia. P.O.Box. 3011 code 1250
}

\begin{abstract}
The study was conducted with the main objectives to see the Determinants of Profitability of Teff Producer Farmers in Menjar Shenkora Worda, North Shewa Zone, Amhara Regional State, Ethiopia. In order to accomplish the stud, both primary and secondary data were used. Primary data were collected from 350 teff producing farm households from 9 selected kebele administrations. For selection of farm households two stage random sampling technique was used. Hence, from 355 samples, 350/ (98.5\%/.) Households were willing to give all necessary information during survey. The data were also analyzed by logistic regression analysis. The regression result reveals that Family size, education level of household head, Distance from market, number of oxen, non-farm income and total costs are statistically significant at $1 \%$ and $5 \%$ level of precision. According to the study findings, the significant variables are the main determinant factors for profitability's of teff producer farmers in the study area. On the other hand, the remaining variables like farmland size, credit access, extension contacts, price determination and amounts of teff productions are found to be statistically insignificant Thus, policy makers should work towards improving the access to more education, access to roads, supply credit to buy more oxen even there is agricultural machine at individual and group level, should create different opportunity to get alternative work or job access to teff producer farmers and some inputs should be subsidize at farm gate level to reduce their total costs of production by making different schemes in the areas.
\end{abstract}

Keywords: Market Performance, Market channel, teff, actors, logistic regression model.

DOI: $10.7176 / \mathrm{JESD} / 12-7-04$

Publication date: April $30^{\text {th }} 2021$

\section{Introduction}

Agriculture plays an important role in economic growth, enhancing food security and poverty reduction in most of developing world. Smallholder agriculture is identified as a vibrant development tool for achieving Millennium Development Goals (World Bank, 2008) for those countries. It is the dominant economic activity in developing countries that contributes about $20 \%$ of the GDP, $60 \%$ of employment and $80 \%$ of the export. When we compare agricultural product of less developed countries with developed countries, the production of agriculture in Developed countries exceeds nine times the product of the former. Agricultural product in many developing countries, are mixed family agriculture that means, many products used for consumption when the left is sold (World Bank, 2004). So, different theoretical literatures and practical works indicate having efficient domestic agricultural commodity marketing system plays a major role in accelerating the profitability of farmers and growth of the agriculture sector. (Mohammed, 2011; Teferi et, al.2017).

In those developing Countries major changes are happening in agricultural and food markets due to globalization, economic liberalization and urbanization (Samueal, 2015). In Africa, there is a large potential for improvements in agricultural production and market development since the last three decades. Africa has more than half of the world's uncultivated land but agriculturally suitable land and has scarcely used its extensive water resources (World Bank, 2013).

Despite the large potential for improvements in agricultural productivity and market performance in Africa, especially given rapid overall economic growth, evidence on changes in domestic food value chains is still limited, possibly due to a lack of accurate, reliable data and information about markets and its related activities (Jerven, 2013). An agricultural value chain can be considered as an economic unit of analysis of a particular commodity or group of commodities that encompasses a meaningful grouping of economic activities that are linked vertically by market relationships. Thus, Agricultural growth remains a viable means of poverty reduction in Africa in general, Sub-Saharan Africa in particular. However, smallholder farmers face high production and transaction costs because of underdeveloped basic infrastructure, such as all-season roads, transport and market facilities, and limited access to productive resources (Barrett, 2008). 
In Ethiopia, the agricultural sector is the most important sector in the economy that features strongly in the overarching economic policy of the country agricultural development led industrialization (ADLI). It serves as source of income and employment for the majority of the country's population. Currently, agriculture is contributing over 35.8 percent to the national GDP, 72.7 percent of employment and 90 percent of export (CIA, 2018). However, the production, productivity and efficiency status of the sector is well below world average. Mostly the farmers with the same resources are producing different per hectare output, because of crops management inefficiency, limited use of modern agricultural technologies, obsolete farming techniques, poor complementary services such as extension, credit, marketing, and infrastructure; poor and biased agricultural policies (FAO 2015 and ATA, 2016).

Ethiopian economy is continued to register a notable growth and agricultural sector showed an impressive growth by $6.4 \%$. Households spend an average of $40 \%$ of their total food budget on cereals (GAIN, 2014). In Ethiopia, in 2016/17 production year, the total grain production reached 290.4million quintals (Qt), of which cereals production accounted $87.42 \%$ (CSA, 2017). Thus, the main cereals crops are teff, barley, maize, wheat and sorghum are the most important crops for Ethiopian agriculture (GAIN, 2014). In Ethiopia, Cereal production and marketing are the means of livelihood for millions of small holder households and it constitutes the single largest sub-sector in economy. Cereal accounts for roughly $60 \%$ of rural employment, $80 \%$ of total cultivated land, more than $40 \%$ of a typical household's food expenditure, and more than $60 \%$ of total caloric intake. The contribution of cereals to national income is also large. According to reports, cereal production represents about $30 \%$ of gross domestic product (GDP). This calculation follows from the fact that agriculture is $48 \%$ of the nation's GDP and that cereals contribute to agricultural GDP is 65\% (Diao et al, 2007)

In Ethiopia, Teff (Eragrostis teff) is cereal grain native to Ethiopia. It is one of the most common and favorite food of majority Ethiopians. It is one of the most important and dominant staple cereal crops in Ethiopia. Besides, it is a major staple food crop for both rural and urban Ethiopian consumers (FAO, 2015). It is used to prepare spongy flat bread called injera which is consumed by about $70 \%$ of the Ethiopian population (Wondmu et al., 2015). Because of its nutritional value and cultural preferences, demand for teff is very high especially in urban areas (Demeke and Marcantonio, 2013). Teff is the most important economic crop cultivated by 43 percent of small households in Ethiopia covering around 31 percent of the total annual cultivation and 21 percent of the total grain production. During the last 24 years the area coverage of teff shows 48 percent increment (from $1,385,700$ ha in1992/1993 to 3,017,914 ha in 2016/17 (CSA, 2017).

The national production and productivity of teff in 2016/17 was estimated around 50.2 million Qt and 16.64Qt per hectar, respectively (CSA, 2017). Teff is producing mainly in Amhara and Oromiya region, which together accounted 84 and $86 \%$ of the total cultivated area, respectively and also A smaller quantity of teff is also produced in Tigray and Southern Nations Nationalities and Peoples (SNNP) region 2.41\% and 6.8\% production, respectively. In those regions, cereal crops account more than $80 \%$ of cultivated land. In $2016 / 17$ production season, in Amhara region, 19.3 million quintal teff are produced which accounts 32\% from total grain produced. In this year teff takes the second rank which accounts $23.7 \%$ next to maize $24.2 \%$ (CSA, 2017).

North Shewa zone is the second leading zone in teff production which constitutes more than $14 \%$ of the annual teff production on the region (CSA, 2017). According to CSA, 2017 report, out of the top 25 teff producer districts, 15 are located in Amhara region. Thus, Menjar shenkora District is one of the main potential teff production districts in the zone. Since agriculture is the major economic activity in the study area. In this area, 356,837 quintals of teff produced per year. Besides, Chickpea, Wheat and Lentil are the major crops of agriculture in the districts.

Thus, that is why this study tries to examine the profitability of teff producer farmers by investigation of many factors like family size, household head level of education, farm land size, Distance from market, Access to credit, Access to Extension service, Price of teff, number of oxen, Volume of teff produced, non-farm income and total transaction costs. To address those variables, the study considers or answers the following two main questions like what are the factors that affect profitability of the farmer in the area? And what are the main obstacles encounters teff producer farmers in the district?

\section{Literature Review}

Since the past two or more decades, different studies have been done to address the determinants of profitability of teff producer farmers in many counties. Those determinant factors have been examined theoretically and empirically by different scholars and studies for different countries. Different studies were made by Mohmmed (2011), Minten et al. (2013), Bayissa (2014), Mebrahatom (2014), Girma (2015), Efa et al. (2016), Fridisa (2016), Adugna (2017) and Azebe and Tadele(2017). From these empirical studies, the following are the main ones:

Mohmmed (2011) studied the determinants of market supply of teff and wheat in Halaba Special District, SNNP, Ethiopia and using applied multiple linear regression models by applications of its cross-sectional data. From the study findings, quantity of teff produced, access to market information, access to extension, and sex of 
the household head were found to have positive and significant influence on market supply of teff in the Halaba area.

Minten et al. (2013) studied the value chain analysis to identify the rural-urban value chain of teff in Addis Ababa, Ethiopia. Using cross-sectional data with questioner and implemented instruments include survey up stream of the value chain with teff producers and communities, midstream, with rural and urban wholesalers and downstream with cereal shop and cooperative retail by descriptive statics method. In addition, from study findings, the conventional wisdom that value chains are relatively short and that average farmer obtains a higher share. About $80 \%$ of the final consumer price in the major terminal market, Addis Ababa. Stock release by farmers is smooth over the year and the importance of distress sales after harvest is lower than commonly assumed.

Bayissa (2014) conducted the Study to examine factors which are influencing adoption decision and intensity of use of improved teff technologies in Western Wollega zone of Ethiopia, used double hurdle model on 140 sample farmers. Results of double-hurdle model confirmed that both adoption and intensity use of improved teff were positively and significantly influenced by sex of the household head, farming experience, participation on crop production training, educational level, yield superiority and maturity period of new varieties. While, the author found that distance to the nearest market place had negative and significance influence on the adoption and intensity use of improved teff varieties.

Mebrahatom (2014) examined the determinants of commercialization of teff and its factor Productivity Outcome in Tahtay Qoraro Woreda, North west Zone of Tigray Regional State, Ethiopia. The study used OLS method and identified that ownership of equine, cash expenses for farming, specialization in teff and total factor productivity, market price of teff and ownership of oxen were those explaining the variation of teff output sale positively while distance from homestead to the nearest market place and distance from homestead to all-weather road found to affect negatively in the district.

Girma (2015) studied the determinants of marketed surplus of teff the case of Baku woreda in South-West Shewa Zone, Oromia National Regional State, Ethiopia, using multiple linear regression models. The result indicated sex, land allocated for teff, market information, and frequency of contact with extension agents on teff production and marketing had a significant effect on the volume of teff marketed in his study area. Based on the above discussed empirical studies we can conclude that most of the factors that affect market participation of each commodity differ from one area to another. Hence, difference in the marketing system of the commodities, type of commodities, use of agronomic practices and location of the study can result in differences in factors affecting market participation and level of participation.

Efa et al., (2016) analyzed determinants of market participation and intensity of marketed surplus of teff producers in Bacho Dawo districts of Oromiya State, Ethiopia using double hurdle econometric model. From study findings, market participation of smallholder farmers is significantly affected by access to credit, perception of farmers on lagged market price of teff, family size, agro ecology, farm size and ownership of transport equipment. Whereas intensity of market participation was significantly influenced by family size, agro ecology, distance to the nearest market, farm size, perception of current price, income from other farming and off-farm activity, and livestock holding from the result of Double Hurdle model. The findings generally suggest the need to create reliable market information, provide good transport facilities for farmers through development of infrastructure, strong extension intervention and giving training to farmers on marketing.

Firdisa (2016) conducted the study on factors determining smallholders ${ }^{\text {ee }}$ participation in teff production in Horo and Jima Geneti districts, Ethiopia. Probit Model estimation procedure was employed to analyze the effects of different explanatory variables on farmersee participation decision in teff production. The results of the probit model revealed that the coefficients of 5 variables were found to be significantly creating variation on the probability of farmers' production participation. The variables that turned out to be significant include: age of the household head, fertility of farm land, number of Oxen owned by the household, family labour and the distance of the households ${ }^{e e}$ residence from extension service. According to the study findings, both smallholder farmers and the local development agents should give attention to those significant variables with care and design a better production strategy focusing on effective supervision, training and approval of appropriate credit institution site so as to enhance the farmers ${ }^{\text {ee }}$ participation in teff production thereby raise productivity of agricultural sector.

Adugna (2017) conducted the study for investigating of the main determinants of teff market supply in Amhara, East Gojam, Huletejenes district, Ethiopia that using cross-sectional data and OLS methods were used. The result indicated that, all market participants were advantaged and generated positive profit from teff market, there is incomparable costs incurred and profit generated among them and also identified shortage of finance and prevalence of crop insects as the major problems of teff traders and farmers. Besides, family size, farm land size, number of oxen are the main determinants factors for profits of teff in the study areas.

Azebe and Tadele(2017) conducted the study to identify factors affecting smallholder farmers' teff supply to the market in Ambo District, West Shewa Zone, Oromia National Regional State of Ethiopia, using multiple 
linear regression models. The result shows that four factors are found to be significantly affects the decision of smallholder farmers on the quantity of teff sold in the market; namely, yield, labor, income non-farm activities, and price of teff.

After critical reviewing of empirical literatures, the present study identified the following gaps. Most of the studies in Ethiopia and other countries used the direct elicitation theoretical approach to measure the market chain analysis in general of many crops. Some of the study mainly focused on the supply side of teff production and ignores the demand side during their studies. While studying the market chain analysis there is a need to check the profit maximization of the farmer with market chain, impact to unobserved selection bias using maximum likelihood procedure. Therefore, there are few studies on the teff market chain analysis and transaction cost in Ethiopia. Thus, this study tried to investigate the main determinants of profitability of teff producer farmers in the district.

\section{Methodology}

\subsection{Research Design}

Research design is a master plan specifying the methods and procedures for collecting and analyzing the needed information. It ensures that the study would be relevant to the problem and that it uses economical procedures. From the types of research design this research was employed descriptive and empirical research. Moreover, the study utilized cross-sectional data in the sense that all relevant data were collected at a single point in time. The reason for preferring a cross-sectional study is because of getting organized long year data was difficult in the area. Obtaining information from a cross-section of a population at a single point in time is a reasonable strategy for pursuing many descriptive researches (Janet et al., 2006).

\subsection{Description of the Study Area}

The study was conducted in North Shoa Zone specifically in Menjar Shenkora district. Minjar Shenkora district, which is one of the 24 districts located in the North Shewa Zone, southern part of Amhara region. The geographical location of the study area lies $9^{\circ} 09^{\prime} 60.00^{\prime \prime} \mathrm{N}$ Latitude and39 19 60.00" E Longitude. Minjar Shenkora district, locating farther to the southern part of North Shewa Zone, is bounded by Hagere Mareyam and Berehet woredas in the north direction and the remaining boundary of Minjar Shenkora is shared with parts of Oromia region in the west, south and east directions.

The study area is located towards the south direction of Debre Birehan-the administrative town of North Shewa Zone- with a distance of $260 \mathrm{~km}$. Minjar Shenkora district is situated towards eastern direction of the capital city of Ethiopia, Addis Ababa having a distance of $130 \mathrm{~km}$ between them.

Minjar Shenkora district is arranged of a total of 29 kebeles, among them the 27 kebeles are part of rural area while the rest two kebeles are included in to the parts of urban areas and it has three agro climatic regions Dega $4.3 \%$, Woinadega $70.9 \%$ and Kola $24.8 \%$. Since agriculture is the major economic activity in the study area the main grains produced are Teff, Chickpea, Wheat and Lentil. Minor grains produced with a very small quantity in Minjar Shenkora district are Barley, Maize, White bean and beans. Among the 24 woredas in the North Shewa Zone, Minjar Shenkora is the well-known area for its highest Teff production. According to the report made by MSWARDB in the 2018/2019cropping season in the study area a total of 48,640.2 hectares of agricultural land was covered with different crops of production.

In the study area 17,106 hectares of agricultural land was covered by the production of Teff. The total amount of Teff harvested in the area is about 356,837 quintals, this is the highest yield amount recorded among all woredas in the North Shewa Zone, and as a result Minjar Shenkora district is the leading district in teff production. According to recent population number projection made by North Shewa zone Finance\& Economic Development (ZOFED, 2017) the total population of Minjarna Shenkora woreda residing in the rural area is estimated to be 125,082 of which 66,246 are males and 58,835 are females. The total urban population of the study area is estimated to be 33,331 of which 15,446 are males and 17,885 are females. Besides, the ethnic distribution in the population of the Minjar Shenkora district comprises few ethnic groups which include Amhara and Oromo as well as some immigrants from other parts of the country. 
Figure 1. Map of the study area

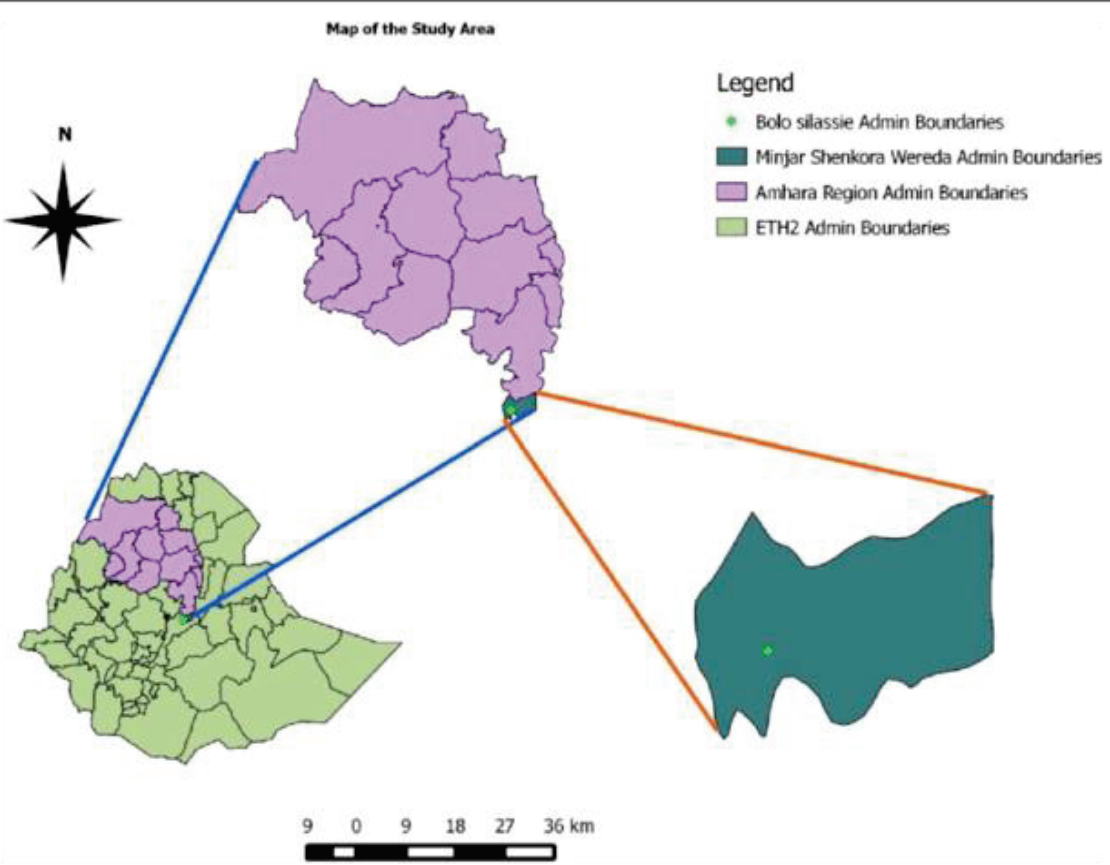

Sources Adapted from GIS, 2017 and own

\subsection{Sample Size Estimation and Sampling Method}

A multistage sampling technique was used to select sample from total teff producers Menjar shenkora has 27 rural kebeles and 2 towns, from $27 \mathrm{kebels}$ and three agro climatic regions Dega agro ecological zone covers 7 kebele, Woina-Dega agro ecological zone covers 12 kebele and Kola agro ecological zone covers 8 kebele (MSDARDB, 2019). The sample of selected kebele for study are 2 kebele from dega , 4 kebele from woinadega and 3 from kebele for kola. Totally, 9 representative teff producer kebeles were selected from the total mentioned kebeles. And 355 sampled household were selected from those selected kebeles. The correct sample size in a study is dependent on the nature of the population and the purpose of the study. The sample size is selected here by considering as representative of sample who participate in farming specially producer of teff crops in the area. To determine the minimum sample size, the study used sample size formula below

Where $\mathrm{n}=$ sample size $\mathrm{p}=$ probability of farmers profitable, $\mathrm{q}=$ probability of farmers not profitable $\mathrm{z}=$ standardized normal value, $\alpha=$ level of significance

$n=\frac{z 2 * p * q}{\propto 2}$

Where: where $\mathrm{n}=$ sample size; $\mathrm{Z}=$ confidence level $(\mathrm{Z}=1.96) ; \mathrm{p}=0.5, \mathrm{q}=1-\mathrm{p}$ and $\mathrm{e}=0.05$ (margin of error) (Dawson, 2009).

Based on Menjar Shenkora worada trade office 2017 report, the study estimated that only $30 \%$ of the farmers in the area are profitable and the left $70 \%$ farmers are not profitable due to different reasons like the problem of high transaction cost and fragmented land. The study set $\mathrm{z}=$ at $95 \%$ and its standardized normal value is $1.96, \mathrm{P}=0.3$ and $\mathrm{q}=0.7 \alpha=0.05$

$n=\left(1.96^{2} * 0.3 * 0.7\right) / 0.05^{2}=322.7 \sim 323+10 \%$ for contingency value of $323=32$ then Total sample size is $355 h h s$. 
Table 1. Sample Distribution for Teff Producer Kebele

\begin{tabular}{|c|c|c|c|c|c|c|c|c|}
\hline No & $\begin{array}{l}\text { Agro } \\
\text { climate } \\
\text { region }\end{array}$ & $\begin{array}{l}\text { Name of } \\
\text { Selected } \\
\text { kebele }\end{array}$ & $\begin{array}{c}\text { Total } \\
\text { land } \\
\text { covered } \\
\text { by all } \\
\text { type } \\
\text { crop } / \mathrm{h} / \mathrm{r}\end{array}$ & $\begin{array}{c}\text { Teff } \\
\text { crop } \\
\text { covered } \\
/ \mathrm{h} / \mathrm{r}\end{array}$ & $\begin{array}{c}\text { Teff } \\
\text { coverage } \%\end{array}$ & $\begin{array}{l}\text { Total No. } \\
\text { teff } \\
\text { producing } \\
\text { household } \\
\text { head }\end{array}$ & $\begin{array}{c}\text { No.of } \\
\text { selected } \\
\text { sample } \\
\text { household } \\
\text { head }\end{array}$ & $\begin{array}{c}\% \text { from } \\
\text { total } \\
\text { household's } \\
\text { head }\end{array}$ \\
\hline \multirow[t]{2}{*}{1} & \multirow[t]{2}{*}{ Dega } & Eranbuti & 1739 & 240 & 13.80 & 1559 & 46 & 13 \\
\hline & & Chercaha & 1280 & 120 & 9.37 & 2666 & 64 & 18 \\
\hline \multirow[t]{4}{*}{2} & \multirow[t]{4}{*}{ Woinadega } & Arerit Zuria & 3429 & 1258 & 36.69 & 1543 & 46 & 13 \\
\hline & & Agerate & 1674 & 834 & 49.82 & 1162 & 32 & 9 \\
\hline & & Amite & 1818 & 616 & 33.88 & 1072 & 32 & 9 \\
\hline & & Rarite & 2214 & 317 & 14.3 & 1370 & 39 & 11 \\
\hline \multirow[t]{3}{*}{3} & \multirow[t]{3}{*}{ Kola } & Cheli & 3685 & 1317 & 35.74 & 1893 & 53 & 15 \\
\hline & & Ketecha & 3194 & 1035 & 32.40 & 580 & 18 & 5 \\
\hline & & Korma & 2198 & 808 & 36.76 & 810 & 25 & 7 \\
\hline \multicolumn{3}{|c|}{ Total sample sum } & 21231 & 6545 & 30.8 & 12655 & 355 & 100 \\
\hline
\end{tabular}

Source: MSWARDO, 2019 and own Computation

\subsection{Data Types and Method of Data Collection}

In order to get the overall picture of teff producers' farmers in the district, the study used both qualitative and quantitative type of data from both primary and secondary source of data. Primary data were collected through the administration of semi-structured and personal interview by a team of 6 trained enumerators to 355 teff producer farmers were considered. Secondary data collect from published and unpublished reports, researcher's website, and already available documents of secondary sources such as Menjar shnkora District Office of Agriculture and Rural Development, and District Trade and Industry Office.

\subsection{Model Specification}

Economics model precise in assessing the relationship between the dependent and explanatory variables and predicts its significance. According to Varian, 1992, Total profit can be estimated as: II= TR-TC: Where, II = profit from teff crop, $\mathrm{TR}=$ total revenue, $\mathrm{TC}=$ total cost.

Let, $\mathrm{TC}=\mathrm{TVC}+\mathrm{TFC}+\mathrm{TRc}$ where $\mathrm{TVC}=$ total variable cost, $\mathrm{TFC}=$ total fixed cost and $\mathrm{TRc}=$ transaction cost therefore, $\mathrm{II}=\mathrm{TR}-\mathrm{TC}-\mathrm{TRc}=Y=\alpha+\beta 1 x 1+\beta 2 x 2+\cdots \beta n x n+e i$

Where:Y stands for vector of " $n$ " observations of dependent variable that indicates the profit

$\beta_{\mathrm{i}}$ is parameter to be estimated, $\mathrm{X}_{\mathrm{i}}$ is a vector of household characteristics and $\varepsilon \mathrm{i}$ is an error term. Finally, the study model is specified as

\footnotetext{
Profitability $=\alpha+\beta_{1}$ Familysize $+\beta_{2}$ Education $+\beta_{3}$ Farmland $+\beta_{4}$ Distance $+\beta_{5}$ CreditAccess $+\beta_{6}$ ExtensionContact $+\beta_{7}$ Price Determination $+\beta_{8}$ Number of Oxen $+\beta_{9}$ Teff production $+\beta_{10}$ Non-farm income $+\beta_{11}$ Total cost $+e i$
} 
Table 2. Description variables used in the logit model

\begin{tabular}{|c|c|c|c|c|c|}
\hline $\begin{array}{l}\text { Variables } \\
\text { type }\end{array}$ & Variables & Variables Description & $\begin{array}{l}\text { Variables } \\
\text { Value }\end{array}$ & Description & $\begin{array}{l}\text { Expected } \\
\text { Sign }\end{array}$ \\
\hline $\begin{array}{l}\text { Dependent } \\
\text { Variable }\end{array}$ & Profit & $\begin{array}{l}\text { Profitable of teff } \\
\text { producer farmer }\end{array}$ & Dummy & $\begin{array}{l}1=\text { if profitable } 0= \\
\text { otherwise }\end{array}$ & \\
\hline \multirow{11}{*}{$\begin{array}{l}\text { Independent } \\
\text { variables }\end{array}$} & Family size & Number of persons & Continuous & Measured in number & $-\mathrm{Nv}$ \\
\hline & $\begin{array}{l}\text { Education } \\
\text { level }\end{array}$ & $\begin{array}{l}\text { Education of the } \\
\text { household }\end{array}$ & Categorical & $\begin{array}{l}\text { Measured in school } \\
\text { year }\end{array}$ & $+\mathrm{Ve}$ \\
\hline & $\begin{array}{l}\text { Farm Land } \\
\text { size }\end{array}$ & $\begin{array}{l}\text { Land size of the } \\
\text { household }\end{array}$ & Continuous & In hectare & $+\mathrm{Ve}$ \\
\hline & Distance & Distance to market & Continuous & In KM & $-\mathrm{Nv}$ \\
\hline & Credit & Access to credit & Dummy & $\begin{array}{l}1=\text { if they have access; } \\
0=\text { otherwise }\end{array}$ & $+\mathrm{Ve}$ \\
\hline & Extension & $\begin{array}{l}\text { Access to Extension } \\
\text { contact }\end{array}$ & Dummy & $\begin{array}{l}1=\text { if they have access; } \\
0=\text { otherwise }\end{array}$ & $+\mathrm{Ve}$ \\
\hline & Set price & $\begin{array}{l}\text { Price setting strategy of } \\
\text { the } \mathrm{HHH}\end{array}$ & Dummy & $\begin{array}{l}11=\text { if they have } \\
\text { determined; } \\
0=\text { otherwise }\end{array}$ & $-\mathrm{Ve}$ \\
\hline & Oxen & Number of Oxen & Continuous & Measured in number & $+\mathrm{Ve}$ \\
\hline & Teff pro & $\begin{array}{l}\text { Total teff production in } \\
\text { quintals }\end{array}$ & Continuous & Quintals & $+\mathrm{Ve}$ \\
\hline & Non-farm & $\begin{array}{l}\text { Non-farm activity of the } \\
\text { HHH }\end{array}$ & Dummy & $\begin{array}{l}\begin{array}{l}1=\text { if participated; } 0= \\
\text { otherwise }\end{array} \\
\end{array}$ & $+\mathrm{Ve}$ \\
\hline & TTcost & $\begin{array}{l}\text { Total production } \\
\text { \&marketing cost }\end{array}$ & Continuous & Measured in birrr & $-\mathrm{Ve}$ \\
\hline
\end{tabular}

Source; Own computation, 2019

\subsection{Model Estimation}

Logistic regression is a nonlinear regression model that forces the output (predicted values) to be either 0 or 1 . Logistic models estimate the probability of dependent variable to be $1(\mathrm{Y}=1)$. This is the probability that some event happens (Greene, 2003). Thus, the dependent variable (the profitability of teff producer farmers) is binary, which takes a value of $\mathrm{y}=1$ if the household is profitable from teff production and the value $\mathrm{y}=0$ if the household is not profitable from teff production by considering the given explanatory variables. Logistic model expresses as,

$$
P\left(y_{i}=1 \mid X_{i}\right)=\Lambda\left(\beta_{0}+\beta X_{i}\right)=\frac{e^{\left(\beta_{0}+\beta X_{i}\right)}}{1+e^{\left(\beta_{0}+\beta X_{i}\right)}}
$$

Where

- $\quad P\left(y_{i}=1 \mid X_{i}\right)$ is the probability that household $i$ is profitable from teff production given the explanatory variables,

- $\quad \Lambda$ is logistic cumulative distribution function,

- $\quad X_{i}$ column vector of explanatory variables and

- $\quad \beta$ row vector of slope of coefficients to be estimated.

Therefore, the logit model has potential to estimate the change in the probability of an event occurring as the result of a unit change in the value of a specific explanatory variable, with the effect of all other explanatory variables held constant. That means, the estimated coefficient of a variable gives the change in the coefficients or log odd as associated with a unit change in the variable, holding all other variables constant (Gujarati, 2009).

\subsection{Diagnosis Tests}

Before fitting important variables into the multiple regression models, it is necessary to test multi-co-linearity problem among continuous variables and check associations among discrete variables, which seriously affect the parameter estimates. According to Gujarati, 2009, multi-co-linearity refers to a situation where it becomes difficult to identify the separate effect of independent variables on the dependent variable because the existing of strong relationship among them. In other words, multi-co-linearity is a situation where explanatory variables are highly correlated. There are two measures that are often suggested to test the existence of multi-co-linearity. 
These are Variance Inflation Factor (VIF) for association among the continuous explanatory variables and Contingency Coefficients (CC) for dummy or discrete variables. Another diagnostic test for heteroscedasticity: that is, diverse variances between residual terms. To detect heteroscedasticity problem the study uses BreuschPagan / Cook-Weisberg test. The result shows that even variance is constant at H0Prob $>$ chi2 $=0.000$ tells us reject $\mathrm{H} 0$, that means there is problem of Heteroscedasticity. To minimize this problem the study used the robust Logistic regression.

\section{Result and Discussion \\ 4.1 Descriptive Analysis}

The study uses descriptive statistics and econometric models. According to survey results, from 355 samples, $350 /(98.5 \% /)$ Households are willing to give all necessary information during survey. The average age of sample household head was 39.9 years old with the maximum and minimum age of 78 years and 24 years respectively. The average family size of sampled respondents was 4.4 persons with standard deviation of 1.83 (minimum 2 and maximum 10 persons). Large number of families would help to direct contribution of more teff production. This is due to the reason that teff production is a labor intensive and it requires continuous follow up. Besides, according to survey results of educational level of respondents, the data indicated that $88.3 \%$ of the sample household head are illiterate and read and write, respectively. However, $11.7 \%$ of the household head had joined the secondary and higher education. And, from 350 of households, $82.8 \%$ of the households are headed by male.

In terms of own farm land, the land size of sample farmers varies from 0.5 to 5 hectare and the average farm size for these sample farmers is found to be 1.5 hectare. The minimum and maximum land allocated for production was 0.5 and 5 hectares respectively. The more land allocated to teff production in the district since they expected to produce more and also profitable. Regarding to distance from home to the nearest teff market center where they sold teff product, sample teff producing respondent reported that the average distance is 20.6 $\mathrm{km}$ with standard deviation of 8.4 and the minimum and maximum distance of $2 \mathrm{~km}$ and $40 \mathrm{~km}$ respectively. The market is available 1day per week in each kebele to transport teff from the field to homestead or home to the market in the study area, farmers used donkeys, animal drawn cart, and carrying by family members.

Access to credit improves and solves financial constraint for small household farmers' production and productivity. Farmers' ability to purchase inputs as improved seed and fertilizer is tied with access to credit. Farmers with access to credit may reduce the effect of financial constraints and able to buy the necessary inputs which improves their teff productivity and production more readily than those with no access to credit. Therefore, it is expected that access to credit can increases production of teff. From the total respondents $88.5 \%$ of households had access to credit and the remaining $11.5 \%$ had no access to credit. Those households who have access to credit receive from their relative and friends in the form of cash or in kind. And, Extension service provision was expected to have direct influence on the production and marketing behavior of the farmers. The higher access to extension services the more likely those farmers to get market information. Thus, Kebele level development agents are the most important sources of extension services. The extension advices from development agents are production, marketing, market information and others. From the total respondents $83.7 \%$ had extension access and to teff producing farmers the remaining $16.3 \%$ had no access.

The role of marketing information for teff producers is that, it reduces risks and uncertainties related to market and enable farm households to make the right decision in sales of the product produced and inputs used in the production process. It is assumed that producers and traders with access to market information can make better decision on how much to produce and how much amount is supplied to the market. From the total respondents $94.5 \%$ had market information for decision making process. Finally, according to sample finding, each household earn 1414. Birr per month from non-farm income:, it produces 11.45 quintals of teff per season , incurs 8835 birr as a total transaction cost in each teff production time and $78 \%$ of households are profitable from their teff production.(See Annex II).

\subsection{Determinants of Teff profitability}

This section presents the econometric estimation of the logit model, in which variables that significantly affect the Profitability of teff producer farmers. In logit estimation, Family size, education level of household head, Distance from market, number of oxen, non-farm income and total costs are statistically significant at $1 \%$ and $5 \%$ level of precision. According to the Logit output results, the significant variables are the main determinant factors for profitability's of teff producer farmers in the study area. On the other hand, the remaining variables like farmland size, credit access, extension contacts, price determination and amounts of teff productions are found to be statistically insignificant (See Table 3.)

The data was estimated using Stata software application version 11.2. From the logit regression result depicted in the below table, we can observe that the explanatory variables identified in the model sufficiently explain variation in the dependent variable, which was shown by high value of Pseudo $\mathrm{R}^{2}(=0.2713)$. Moreover, 
probability of chi $^{2}$ is statistically significant at 1 percent, which indicates that all explanatory variables taken together are significant in explaining the dependent variable in the model.

Before estimating, the study used different diagnostic test for ${ }^{1}$ Multicollinearity is tested by the ${ }^{2}$ VIF, ${ }^{3} \mathrm{TOL}$ test and ${ }^{4}$ Spearman's correlation coefficient matrix for Access to formal financial credit model. From the findings, the correlation coefficient values are not found to show perfect correlation (negative and positive) between the variables. ${ }^{5}$ Heteroscedasticity is also tested by Breusch-Pagan test. The test assures the presence of heteroscedasticity (has not constant variance in the $\varepsilon_{\mathrm{i}}$ ) and study regressed by robust Logistic regression to solve the problems. Therefore, the model can be valid to determine variables that significantly affect the profitability of teff producer farmers in the study area.

After identifying the main determinant factors for profitability of teff producer farmers by logit model the marginal effect of method used to estimate the explanatory variables on dependent variables. As can be seen from Table 3, Family size, education level of household head, Distance from market, number of oxen, non-farm income and total costs are statistically significant at $1 \%$ and $5 \%$ level of precision. According to the Logit output results, the significant variables are the main determinant factors for profitability's of teff producer farmers in the study area. On the other hand, the remaining variables like farmland size, credit access, extension contacts, price determination and amounts of teff productions are found to be statistically insignificant (See Table 3.). Thus,

The coefficient of family size is positive; it shows that household with more family members are more likely to be profitable than households with small family members, It means that, if households size increases by one more family member, keeping other variables constant, the profit from teff production increases by $3 \%$ on average level. This can be due to more family members have more probability to have more labor for teff production and the farming of teff is the labor-intensive crop production and it requires continuous follow up in farming activities that needs more labor for whole production system than small size family members. And thereby increases the production and profitability of teff. This finding is similar to the works of ( Bayissa ,2014, Mebrahatom, 2014, Girma, 2015, Efa et al., 2016 and Firdisa ,2016).

The coefficient of household education level is positive; it shows that household with higher education level of the head are more likely to be profitable relative to households with lower level of education. It means that, if households with one more education grade level, keeping other variables constant, profit from teff production increases by $23 \%$ on average level. This can be due to education improves the production of teff ability than households with low level of education and thereby increases profitability of teff production. This finding is similar to the works of ( Bayissa ,2014, Mebrahatom, 2014, Girma , 2015, Efa et al., 2016 and Firdisa ,2016).

The coefficient of Distance from market is negative; it indicates households with distant or far from market have less probability to get more profit than households with short distance of market. It means that, if distance of market increases by one more kilometer from teff producer farmer houses, keeping other variables constant, the probability of profitability from teff production decreases by $0.01 \%$. This can be due to when the farmers far away from teff market, the teff producer can incur more different costs like transportation costs, information costs and other related production cost relative to the farmer who near to the teff markets. This finding is similar to the works of ( Bayissa ,2014, Mebrahatom, 2014, Girma , 2015, Efa et al., 2016 and Firdisa ,2016).

\footnotetext{
${ }^{1}$ Multicollinearity means the existence of perfect or exact linear relationship between two or more explanatory variables in the regression model.

${ }^{2}$ Variance inflating factor measures the speed with which variance and covariance increase. It is computed as VIF $=\frac{1}{1-r 2}$, Where: $r^{2}$ is

Correlation Coefficient, then, VIF $=1.49, \mathrm{r}^{2}=0.329$

${ }^{3} \mathrm{TOL}=1 / \mathrm{VIF}$ or $1-\mathrm{r}^{2}=1 / 1.49=0.671$

${ }^{4}$. All Spearman's correlation coefficients are below 0.8 .

${ }^{5}$ The probability distribution of random variables $\left(\mathrm{u}_{\mathrm{i}}\right)$ is the same over all observation of $\mathrm{x}$, and in particular that the variance of each $\mathrm{u}_{\mathrm{i}}$ is that same for all values of the explanatory variables $\operatorname{Var}\left(\mathrm{u}_{\mathrm{i}}\right)=\mathrm{E}\left\{\left(\mathrm{u}_{\mathrm{i}}-\mathrm{E}\left(\mathrm{u}_{\mathrm{i}}\right)\right\}^{2}=\mathrm{E}\left(\mathrm{u}_{\mathrm{i}}\right)^{2}=\delta^{2}=\right.$ Constant variance.

Heteroscedasticity is also tested by Breusch-Pagan test as $\mathrm{Chi}^{2}(11)=26.07 .00(0.006)$.
} 
Table 3. Logit Estimation for determining of profitability of teff producer farmers

\begin{tabular}{|c|c|c|}
\hline \multirow[t]{2}{*}{ Explanatory variables } & \multicolumn{2}{|c|}{ Dependent variable Y 1 Profitable of teff producer, 0 , otherwise } \\
\hline & Logit Output & Marginal effects $d y / d x$ \\
\hline Family size & $\begin{array}{l}0.2035^{* *} \\
(.0982)\end{array}$ & $\begin{array}{l}0.0251 * * \\
(0.0126)\end{array}$ \\
\hline Education status (EDU) & $\begin{array}{l}1.3437 * * * \\
(0.4446)\end{array}$ & $\begin{array}{l}0.2301 * * \\
(0.0946\end{array}$ \\
\hline Farm land size & $\begin{array}{l}-0.2683 \\
(0.3660)\end{array}$ & $\begin{array}{l}-0.0332 \\
(0.0463)\end{array}$ \\
\hline Distance from market & $\begin{array}{l}-0.0444 * * * \\
(0.0159)\end{array}$ & $\begin{array}{l}-0.0055 * * * \\
(0.0021)\end{array}$ \\
\hline Credit Access & $\begin{array}{l}0.5125 \\
(0.4028) \\
\end{array}$ & $\begin{array}{l}0.0726 \\
(0.0655)\end{array}$ \\
\hline Extension Contact & $\begin{array}{l}0.1562 \\
(0.4027)\end{array}$ & $\begin{array}{l}0.0201 \\
(0.0532)\end{array}$ \\
\hline Price Determination & $\begin{array}{c}-0.1868 \\
(0.3178)\end{array}$ & $\begin{array}{l}-0.0229 \\
(0.0389)\end{array}$ \\
\hline Number of Oxen & $\begin{array}{l}0.8707 * * * \\
(0.2864)\end{array}$ & $\begin{array}{l}0.1076 \text { *** } \\
(0.0273)\end{array}$ \\
\hline Teff Production in quintal & $\begin{array}{l}-0.0159 \\
(0.0598)\end{array}$ & $\begin{array}{l}-0.0020 \\
(0.0074)\end{array}$ \\
\hline Non-farm Income & $\begin{array}{l}0.0001 * * \\
(0.00004) \\
\end{array}$ & $\begin{array}{l}0.0001 * * \\
(0.00001)\end{array}$ \\
\hline Total Costs & $\begin{array}{l}-0.0003 * * * \\
(0.00005)\end{array}$ & $\begin{array}{l}-0.0003 * * * \\
(0.0001)\end{array}$ \\
\hline Constant & $\begin{array}{l}2.0953 \\
(0.8037)\end{array}$ & \\
\hline Pseudo $\mathrm{R}^{2}$ & 0.2718 & - \\
\hline Wald chi $^{2}(11)$ & $\mathbf{5 7 . 5 3}$ & \\
\hline Prob $>$ chi $^{2}$ & 0.000 & \\
\hline Number of Observation & 350 & 350 \\
\hline
\end{tabular}

$* * *$ Significance at 1\%,** significance at 5\%, $*$ significance at 10\%, Standard error is in bracket.

Source: Household survey, 2019.

The coefficient of number of oxen is positive; it shows that household with more oxen are more likely to be profitable relative to households with few numbers of oxen, it means that, if households with one more ox for teff production, keeping other variables constant, the profit from teff production increases by $11 \%$ on average level. This can be due to More oxen have more probability to plough teff lands and collecting, harvesting and winnowing teff in the area than households with few oxen number. This finding is similar to the works of ( Bayissa ,2014, Mebrahatom, 2014, Girma , 2015, Firdisa ,2016, Azebe and Tadele, 2017 and Adugna ,2017).

The coefficient of non-farm income is positive; it shows that household with more non -farm income is more likely to be profitable relative to households with low non-farm income. It means that, if household's nonfarm income increases by $1 \%$, keeping other variables constant, the profit from teff production increases by $0.1 \%$ on average level. This can be due to households who have an opportunity to generate or get non-farm income; they have an opportunity to cover their costs of living in their homes, they also have more opportunity to by different inputs for their teff production activities than households with lees non- farm income households. ( Bayissa ,2014, Mebrahatom, 2014, Girma , 2015, Firdisa ,2016, Azebe and Tadele, 2017 and Adugna ,2017).

The coefficient of total costs is negative; it indicates households with high total costs have less probability to get more profit than households with small cost teff farmer. It means that, if the total costs of teff production increases by $1 \%$, keeping other variables constant, the probability of profitability from teff decreases by $0.01 \%$. This can be due to the farmers' production costs increases due to input price increase, transaction costs from selling may raise for distant farmers from markets, less access to road to the market's farmers in the study area, etc. ( Bayissa ,2014, Mebrahatom, 2014 , Girma , 2015, Firdisa ,2016, Azebe and Tadele, 2017 and Adugna ,2017).

\section{Conclusion and Recommendations}

Teff is the most important cereal crop in terms of food consumption and cash formation in Ethiopia. The study was conducted in Menjare shenkora district of Amara Regional state in North Shewa, Ethiopia. The study was conducted with main objectives for determinants of profitability's of teff producer farmers in the study area. In 
order to accomplish study objectives both primary and secondary data were used. Primary data were collected from 350 teff producing farm households from selected 9 kebele administrations in Menjare shenkora district. For selection of farm households two stage random sampling technique was used. Secondary data were collected from Menjar shenkora District Agriculture and Natural Resource office, Trade and Industry Office reports, bulletins, websites, published and unpublished documents and others.

According to survey results, from 355 samples, 350/ (98.5\%/.) Households are willing to give all necessary information during survey. The average age of sample household head was 39.9 years old with the maximum and minimum age of 78 years and 24 years respectively. The average family size of sampled respondents was 4.4 persons with standard deviation of 1.83 (minimum 2 and maximum 10 persons). Besides, according to survey results of educational level of respondents, the data indicated that $88.3 \%$ of the sample household head are illiterate and read and write, respectively. However, $11.7 \%$ of the household head had joined on secondary and higher education. And, from 350 households, $82.8 \%$ of the households are headed by male. In terms of own farm land, the land size of sample farmers varies from 0.5 to 5 hectare and the average farm size for these sample farmers is found to be 1.5 hectare. The minimum and maximum land allocated for production was 0.5 and 5 hectares respectively. Regarding to distance from home to the nearest teff market center where they sold teff product, sample teff producing respondent reported that the average distance is $20.6 \mathrm{~km}$ with standard deviation of 8.4 and the minimum and maximum distance of $2 \mathrm{~km}$ and $40 \mathrm{~km}$ respectively.

Those households who have access to credit receive from their relative and friends in the form of cash or in kind. From the total respondents $88.5 \%$ of households had access to credit and the remaining $11.5 \%$ had no access to credit. And, Extension service provision was expected to have direct influence on the production and marketing behavior of the farmers. From the total respondents $83.7 \%$ had extension contact services. From the total respondents $94.5 \%$ had market information for decision making process. Finally, according to sample finding, each household earn 1414. Birr per month from non-farm income: it produces 11.45 quintals of teff per season, incurs 8835 birr as a total transaction cost in each teff production time and $78 \%$ of households are profitable from their teff production. (See Annex II).

Moreover, the regression result reveals that Family size, education level of household head, Distance from market, number of oxen, non-farm income and total costs are statistically significant at $1 \%$ and $5 \%$ level of precision. According to the Logit output results, the significant variables are the main determinant factors for profitability's of teff producer farmers in the study area. On the other hand, the remaining variables like farmland size, credit access, extension contacts, price determination and amounts of teff productions are found to be statistically insignificant

Thus, policy makers should work towards improving the access to more education, access to roads, supply credit to buy more oxen even there is agricultural machine at individual and group level, creat different opportunity to get alternative work or job access to teff producer farmers and some inputs should be subsidize at farm gate level to reduce their total costs of production by making different schemes in the areas. Finally, in the areas of future research, this study is a cross sectional study which is a one-time snapshot and did not enable us to see the dynamics of the

Profitability of teff producer in the study areas well as in the region and the country too. And, all mentioned factors are not also the only variables that to predict the main determinants of teff producer farmers in the area or elsewhere in the country. Hence, Similar other studies or future researchers should be focused to cover unstudied areas so as to drive a Meta-data for the zone, the region as well as the country as a whole. And, if similar other studies need to be conducted in the district, they need to be innovative enough to include other more variables (determinants) that are beyond the present study by using more samples.

\section{References}

Adugnaw, A. (2017). Analysis of teff (Eragrostistef) market chain: The case of HuletEjEnese District, East Gojam Zone, Amhara Region, Ethiopia. MSc Thesis, Haramaya University, Ethiopia.

ATA (Agricultural Transformation Agency) (2016). Transforming Agriculture in Ethiopia. Annual report $2015 / 2016$

Azebe,B and Tadele,M.(2017). Determinants of smallholder farmers in teff market supply in Ambo District, West Shewa Zone of Oromia, Ethiopia. International Journal of advanced research in management and social sciences, 6(2): 133-140.

Barrett,B.(2008). Smallholder market participation: Concepts and evidence from Eastern and Southern Africa. Food Policy 33(4):299-317.

Bayissa ,G.(2014). A Double-Hurdle Approach to Modeling of Improved Teff Technologies Adoption and Intensity Use: The case of Diga district of East Wollega Zone, Ethiopia. Global Journal of Environmental Research, 8(3), 41-49.

CIA (Central Intelligence Agency) (2018). The Work of A Nation, Ethiopian Economy Profile. CIA World Fact Book. 
Creswell,W.(2009).Research Design: Qualitative, Quantitative, and Mixed Methods Approaches, 3rd edition, Landon, Sega publications.

CSA (2016). Agricultural Sample Survey Report on Area and Production of Major Crops (private peasant holdings, Belg season 2015 / 2016 (2008 E.C.). Addis Ababa, Ethiopia.

CSA (2017) Agricultural Sample Survey 2016/2017 (2009 E.C). Volume I report on area and production of major crops (private peasant holdings, meher season), Addis Ababa, Ethiopia.

CSA (2017). Agricultural Sample Survey. Report on Area and Production of Major Crops, Addis Ababa, Ethiopia.

Dawson, C. (2009). Introduction to Research Methods: A practical guide for any one undertaking a research project, 4th edition, United Kingdom, Books Ltd.

Demeke, M and Marcantonio, F. (2013). Analysis of Incentives and Disincentives for Teff In Ethiopia. Technical Notes Series, FAO, Rome., Italy.

Diao X., Belay F., Steven H., Alemayehu S., Kassu W., Bingxin Y. (2007), Agricultural Growth Linkages in Ethiopia: Estimating using Fixed and Flexible Price Models. IFPRI discussion paper no 00695: 8-30

Efa ,G., Degye,G., Tinsae,D., and Tadesse,K. (2016). Determinants of Market Participation and Intensity of Marketed Surplus of Teff Producers in Bacho And Dawo District, Ethiopia. Journal of Agricultural Economics, 5(2): 020-032.

FAO (Food and Agricultural Organization). (2015). Analysis of Price Incentives for Teff In Ethiopia. Technical Notes Series, MAFAP, FAO, Rome., Italy.

Firdisa, B.(2016). Determinants of Smallholder Farmers' Participation Decision in Teff Production: Evidence from Horo And Jimma Geneti Woreda, Ethiopia. Developing Country Studies, 6(10).

GAIN (Global Agricultural Information Network),2014. Ethiopia Grain and Food Manual Report, Number ET1401

Girma, A. (2015). Market Performance and Determinants of Marketed Surplus of Teff, In the Case of Bacho Woreda In South West Shewa Zone, Oromia National Regional State. Msc Thesis, Haramaya University, Haramaya, Ethiopia.

Greene W. H. (2003). Econometric Analysis, Fifth edition. New Jersey, 07458. USA: Pearson Education, Inc., Upper Saddle River,

Gujarati, D. (2009). Basic Econometrics. 4th Edition. Tata McGraw-Hill Publishing Company Limited, New Delhi, India.

Janet,M., and Ruane (2006).Essentials of Research Methods. A Guide to Social Science Research. USA, Blackwell Publishing.

Jerven, M. (2013). Poor Numbers: How We Are Misled by African Development Statistics and What to Do About It. Ithaca, NY: Cornell University Press.

Mebrahatom, M. (2014). Determinants of Commercialization of Teff And Its Factor Productivity Outcome: The Case of Tahtay Qoraro Woreda, Northwest Zone of Tigray Regional State, Ethiopia. Msc Thesis, Haramaya University, Ethiopia.

Minten B, Tamru S, Engida E, and Kuma T (2013). Ethiopia's Value Chain on The Move: The Case of Teff. ESSP Working Paper Series, 52, 1-26.

Mohammed,U.(2011). Market Chain Analysis of Teff And Wheat Production in Halaba special District, Ethiopia. Msc Thesis, Haramaya University,Haramaya, Ethiopia.

MSDARDB (2019). Minjar Shenkora District Agriculture and Rural Development Bureau2018/19 Annual report.

MSDTIDB (2018). Minjar Shenkora District Trade and Industry Development Bureau 2018 Annual report.

Samuel, H. (2015). Assessing the Resilience of the Teff Value Chain in Ethiopia. Department of Environmental Systems Science and Chair of Sustainable Agro-Ecosystems, Swiss Federal Institute of Technology Zurich, Switzerland.

Teferi G. and Getamesay B. (2017). Market Chain for Cereal and Pulse Crops in North Shewa Zone of Oromia Regional State (Ethiopia),7(2): 249-269 Macro Think Institute, USA.

Tsakok, I. (2011). Success in Agricultural Transformation. Cambridge: Cambridge University.

Varian,H. (1992).Microeconomics Analysis 3rd Edition Library of Congress Cataloging-in-Publication Washington Dc, USA.

Wondimu, T., Teshome, A., and Gezahegn, B (2015). Economic Analysis of Teff Yield Response to Different Sowing Methods: Experience, Illuababora Zone, Ethiopia. Journal of Economics and Sustainable Development, 6(1).

World Bank (2004). Poverty Reduction and Economic Management, Country Department for Ethiopia: Opportunities and Challenges for Developing High-value Agricultural exports in Ethiopia, Africa region, background report, Washington, USA.

World Bank (2007). Explaining Sources of Food Price Inflation in Ethiopia: “A Just in Time Policy Note", 14-28

World Bank (2008). Millennium Development Goals. Retrieved On 22rd Nov, 2018 From 
Www.Worldbank.Org/Mdgs/Poverty-Hunger.Html.

World Bank (2013). Agri-Business in Africa: Removing Barriers to Regional Trade to Food Staples. Washington, DC.

World Bank (2014). World Development Indicators, Agriculture and Rural Development.

World Bank (2016). World Development Indicators, Agriculture and Rural Development.

ZOFED, (2017). North Shewa Zone Finance \& Economic Development 2016/17 Annual Population Size Report.

\section{Annex I: Conceptual Definition of few terms}

A household: is a group of rural persons who live together under the responsibilities of the head and eat from the same pot.

Kebele: is the lowest administrative body in Ethiopia which comprises at least 5000 people.

Smallholder farmers: farmers that plough small area of land for their agricultural practice; or farmers that do not own an intensive commercial farm.

Transaction Cost: -The type of cost that deserved when swapping goods/services on the market, such as: contract enforcement costs, search and information costs, commissions to intermediaries (Williamson, 2002)

Market chain: Is used to describe the numerous links that connect all actors and transactions involved in the movement of agricultural products from the farm to the consumer (Lunndy et al., 2004).

Annex II: Result for Descriptive Analysis.

. summarize profitabilityyes10other age sex famsize educatlev farmlandsize distancefrommkt creditaccess extenstionaccess mrkinfacces > s pricedeterm numberofoxen teffproduequental nonfarmincom ttcost

\begin{tabular}{r|rrrrr} 
Variable & obs & Mean & Std. Dev. & Min & Max \\
\hline profitabi1 r & 350 & .7828571 & .4128909 & 0 & 1 \\
age & 350 & 39.92857 & 10.71902 & 24 & 78 \\
sex & 350 & .8285714 & .3774226 & 0 & 1 \\
famsize & 350 & 4.4 & 1.835655 & 2 & 10 \\
educatlev & 350 & .1171429 & .3220508 & 0 & 1 \\
\hline farmlandsize & 350 & 1.5045 & .7946112 & .5 & 5 \\
distancefr t & 350 & 20.61429 & 8.734697 & 2 & 40 \\
creditaccess & 350 & .8857143 & .3186135 & 0 & 1 \\
extenstion s & 350 & .8371429 & .3697639 & 0 & 1 \\
mrkinfaccess & 350 & .9457143 & .226905 & 0 & 1 \\
\hline pricedeterm & 350 & .5542857 & .4977559 & 0 & 1 \\
numberofoxen & 350 & 2.157143 & 1.094866 & 1 & 6 \\
teffprodue 1 & 350 & 11.45429 & 4.276198 & 1 & 31 \\
nonfarmincom & 350 & 1414.226 & 3554.684 & 0 & 21080 \\
ttcost & 350 & 8815.225 & 3191.263 & 5000 & 19632
\end{tabular}

\section{Annex III: Results for Logit with Robust standard error}

- logit profitabilityyes10other famsize educatlev farmlandsize distancefrommkt creditaccess extenstionaccess pricedeterm numberofoxe $>\mathrm{n}$ teffproduequental nonfarmincom ttcost, vce(robust)

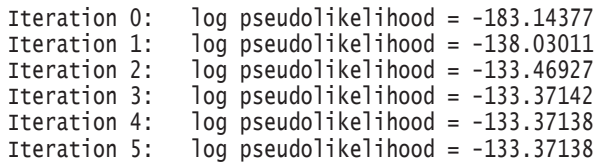

Logistic regression

Log pseudolikelihood $=-133.37138$

$\begin{array}{llr}\text { Number of obs } & = & 350 \\ \text { Wald chi2(11) } & = & 57.53 \\ \text { Prob chi2 } & = & 0.0000 \\ \text { Pseudo R2 } & = & 0.2718\end{array}$

\begin{tabular}{r|rcrrrr}
\hline \multirow{2}{*}{ profitabi1 r } & Coef. & $\begin{array}{l}\text { Robust } \\
\text { Std. Err. }\end{array}$ & $\mathrm{z}$ & $\mathrm{P}>|\mathrm{z}|$ & [95\% Conf. & Interva1] \\
\hline famsize & .2034536 & .0982349 & 2.07 & 0.038 & .0109168 & .3959905 \\
educatlev & -1.343715 & .4446551 & -3.02 & 0.003 & -2.215223 & -.4722074 \\
farmlandsize & -.2683005 & .3660284 & -0.73 & 0.464 & -.9857029 & .449102 \\
distancefr t & -.0444303 & .0159506 & -2.79 & 0.005 & -.0756929 & -.0131678 \\
creditaccess & .5124659 & .4028404 & 1.27 & 0.203 & -.2770867 & 1.302019 \\
extenstion s & .1561734 & .4027595 & 0.39 & 0.698 & -.6332208 & .9455676 \\
pricedeterm & -.1868115 & .3178127 & -0.59 & 0.557 & -.809713 & .43609 \\
numberofoxen & .8707267 & .286363 & 3.04 & 0.002 & .3094655 & 1.431988 \\
teffprodue 1 & -.015857 & .0597945 & -0.27 & 0.791 & -.1330522 & .1013381 \\
nonfarmincom & .0001147 & .0000478 & 2.40 & 0.017 & .0000209 & .0002084 \\
ttcost & -.0002354 & .0000495 & -4.75 & 0.000 & -.0003324 & -.0001383 \\
_cons & 2.095268 & .8036521 & 2.61 & 0.009 & .5201393 & 3.670398
\end{tabular}


Annex IV: Results for marginal effects.

. $\mathrm{mfx}$

Marginal effects after logit

$y=\operatorname{Pr}($ profitabilityyes10other) (predict)

$=.855538$

\begin{tabular}{|c|c|c|c|c|c|c|c|}
\hline variable & $d y / d x$ & Std. Err. & z & $\mathrm{P}>|\mathrm{z}|$ & $95 \%$ & C.I. & $\mathrm{X}$ \\
\hline fams & 251454 & 01263 & 99 & 0.046 & .000397 & 049893 & 4.4 \\
\hline educat $V^{*}$ & -.2300085 & .09455 & -2.4 & 0.015 & -.415319 & -.044698 & .117143 \\
\hline farmla e & -.03316 & .04626 & -0.72 & 0.473 & -.123831 & .057511 & 1.5045 \\
\hline distan t & -.0054913 & .00211 & -2.60 & 0.009 & -.009627 & -.001356 & 20.6143 \\
\hline credit $\sim S^{*}$ & .0726451 & .06546 & 1.11 & 0.267 & -.055655 & . 200945 & .885714 \\
\hline extens $\sim$ * & .020036 & .05312 & 0.38 & 0.706 & -.08408 & .124152 & .837143 \\
\hline priced m* & -.0229311 & .03885 & -0.59 & 0.555 & -.099082 & .05322 & .554286 \\
\hline number $n$ & 1076155 & .02726 & 3.95 & 0.000 & .054193 & .161038 & 2.15714 \\
\hline teffpr 1 & -.0019598 & .00735 & -0.27 & 0.790 & -.01637 & .01245 & 11.4543 \\
\hline nonfar m & .0000142 & .00001 & 2.27 & 0.023 & $2.0 \mathrm{e}-06$ & .000026 & 1414.23 \\
\hline ttcost & -.0000291 & .00001 & 4.61 & 0.000 & -.000041 & -.000017 & 8815.23 \\
\hline
\end{tabular}

(*) $d y / d x$ is for discrete change of dummy variable from 0 to 1 